\title{
Rapid Reduction of Severely Elevated Serum Triglycerides with Insulin Infusion, Gemfibrozil and Niacin
}

\author{
Sujani Poonuru, MD; Sumedha R. Pathak, MD; Hemender S. Vats, MD; and Ram D. Pathak, MD
}

\begin{abstract}
The conventional methods of treatment of severe hypertriglyceridemia are dietary restriction and lipid lowering medications, mainly fibric acid derivatives. In the medical literature, use of insulin infusion to treat hypertriglyceridemia has not been highlighted sufficiently. We report a 53-year-old male who presented with a four-day history of epigastric pain. The patient's clinical history was significant for hypertriglyceridemia, type-2 diabetes mellitus with medication noncompliance, obesity, status post-gastric bypass surgery, and alcohol abuse with prior admissions for detoxification. Physical examination revealed mild epigastric tenderness. Laboratory studies revealed severely elevated serum triglyceride (TG) level $(8116 \mathrm{mg} / \mathrm{dL})$. Computed tomography (CT) scan of the abdomen exhibited no evidence of pancreatitis. Regular insulin infusion was started at $3 \mathrm{U} / \mathrm{h}$ and gradually increased to 7-10 $\mathrm{U} / \mathrm{h}$. Dextrose infusion was titrated to avoid hypoglycemia and maintain blood glucose levels below $150 \mathrm{mg} / \mathrm{dL}$. Gemfibrozil and niacin were also started.After 24 hours, his TG levels were decreased to $250 \mathrm{I} \mathrm{mg/dL}$. Insulin infusion was continued for about 48 hours. A low carbohydrate diet excluding simple carbohydrates was given. The patient's serum TG levels normalized over a period of one month. Thus insulin infusion can be considered a safe modality of treatment for rapid reduction of serum TG in addition to fibrates and niacin.
\end{abstract}

Keywords: Acute pancreatitis; Hypertriglyceridemia; Insulin

Corresponding Author:

Ram D. Pathak, MD

Department of Endocrinology

Marshfield Clinic

1000 North Oak Avenue

Marshfield WI 54449

Tel: $7|5-387-548|$

Fax:715-389-5757

Email: pathak.ram@marshfieldclinic.org

Received: November 10, 2009

$1^{\text {st }}$ Revision: February 26, 2010

$2^{\text {nd }}$ Revision: May II, 2010

Accepted: May 19, 2010

doi: $10.3|2| / \mathrm{cmr} .2010 .898$
I n patients with severe hypertriglyceridemia (HTG), the risks for development of acute pancreatitis and premature atherosclerosis are elevated. Insulin is a potent triglyceride (TG)-lowering agent that acts by promoting the synthesis of lipoprotein lipase which is the crucial enzyme for the hydrolysis of TG. ${ }^{1}$ In patients with severe HTG, immediate lowering of the TG level to below $1000 \mathrm{mg} / \mathrm{dL}$ is possible with insulin infusion, while long-term maintenance therapy can be provided with utilization of other pharmacological agents, such as fibrates, niacin and fish oil.

\section{Clinical Presentation}

A 53-year-old male presented with epigastric pain of four-day duration. The patient's medical history included HTG, coronary artery disease, type-2 diabetes mellitus, obesity, status post-gastric bypass surgery 15 years ago, alcohol abuse (12 cans of beer/day) with prior admissions for detoxification, obstructive sleep apnea and leg cramps secondary to statin use. He was on ezetemibe $10 \mathrm{mg}$ daily, gemfibrozil $600 \mathrm{mg}$ twice daily, metoprolol $100 \mathrm{mg}$ daily, and clopidogrel $75 \mathrm{mg}$ once daily. A family history of premature coronary artery disease in his father and brothers was present. He denied alcohol consumption recently. On examination, the patient weighed $93 \mathrm{~kg}$ (body mass index of $32 \mathrm{~kg} / \mathrm{m} 2$ ) and exhibited central 
Table 1. Summary of laboratory test results.

\begin{tabular}{|c|c|c|c|c|}
\hline Laboratory Test & Reference Range & Day 1 & Day 2 & Day 3 \\
\hline Pancreatic amylase & $12-50 \mathrm{U} / \mathrm{L}$ & $20 \mathrm{U} / \mathrm{L}$ & $18 \mathrm{U} / \mathrm{L}$ & $15 \mathrm{U} / \mathrm{L}$ \\
\hline Lipase & $91 \mathrm{U} / \mathrm{L}$ & $91 \mathrm{U} / \mathrm{L}$ & $58 \mathrm{U} / \mathrm{L}$ & $52 \mathrm{U} / \mathrm{L}$ \\
\hline Total Cholesterol & $100-200 \mathrm{mg} / \mathrm{dL}$ & 1244 mg/dL & 1033 mg/dL & $747 \mathrm{mg} / \mathrm{dL}$ \\
\hline High Density Lipoprotein & $40-59$ mg/dL & 25 mg/dL & 74 mg/dL & 38 mg/dL \\
\hline Serum Triglycerides & $20-150 \mathrm{mg} / \mathrm{dL}$ & $8116 \mathrm{mg} / \mathrm{dL}$ & $2501 \mathrm{mg} / \mathrm{dL}$ & $1765 \mathrm{mg} / \mathrm{dL}$ \\
\hline Aspartate aminotransferase & 15-46 U/L & $91 \mathrm{U} / \mathrm{L}$ & 65 U/L & $39 \mathrm{U} / \mathrm{L}$ \\
\hline Alanine aminotransferase & $10-61 \mathrm{U} / \mathrm{L}$ & $45 \mathrm{U} / \mathrm{L}$ & $36 \mathrm{U} / \mathrm{L}$ & 27 U/L \\
\hline Total alkaline phosphatase & 40 to $125 \mathrm{U} / \mathrm{L}$ & $137 \mathrm{U} / \mathrm{L}$ & $123 \mathrm{U} / \mathrm{L}$ & $107 \mathrm{U} / \mathrm{L}$ \\
\hline Random blood glucose & & 122 mg/dL & $127 \mathrm{U} / \mathrm{L}$ & 117 U/L \\
\hline Creatinine & $0.7-1.3 \mathrm{mg} / \mathrm{dL}$ & $0.9 \mathrm{mg} / \mathrm{dL}$ & $1.0 \mathrm{mg} / \mathrm{dL}$ & $0.9 \mathrm{mg} / \mathrm{dL}$ \\
\hline Thyroid Stimulating Hormone & $0.46-4.48 \mu \mathrm{lU} / \mathrm{mL}$ & $1.78 \mu \mathrm{lU} / \mathrm{mL}$ & & \\
\hline Hemoglobin A1C & $4.0-6.0 \%$ & $6.9 \%$ & & \\
\hline Blood alcohol & & negative & & \\
\hline
\end{tabular}

obesity. He was afebrile; blood pressure was 130/74 $\mathrm{mmHg}$ and pulse was 84 beats per minute. Abdominal examination revealed mild epigastric tenderness with no rigidity or guarding. Eruptive cutaneous xanthomas, or lipemia retinalis were absent. Lipemic plasma with serum TG $8116 \mathrm{mg} / \mathrm{dL}$ was remarkable. Laboratory results are summarized in table 1.

Computed tomography scan of the abdomen was negative for pancreatitis. The patient was admitted and kept fasting. Regular insulin infusion was started at $3 \mathrm{U} / \mathrm{h}$ and gradually increased to 7 to $10 \mathrm{U} / \mathrm{h}$. Dextrose infusion was titrated to avoid hypoglycemia and maintain blood glucose levels below $150 \mathrm{mg} / \mathrm{dL}$. Insulin infusion was continued for about 48 hours. He did not have any significant hypoglycemia during this treatment. Gemfibrozil (600 $\mathrm{mg}$ twice a day) and niacin ( $250 \mathrm{mg} /$ day) were started at the same time. Within 24 hours, epigastric pain resolved. The patient's TG and lipase levels decreased to $2501 \mathrm{mg} / \mathrm{dL}$ and $52 \mathrm{U} / \mathrm{L}$, respectively. His diet was advanced slowly. A low carbohydrate diet excluding simple carbohydrates was given. On the third day, the triglyceride levels showed further reduction to $1765 \mathrm{mg} / \mathrm{dL}$, and the patient was discharged on request. He refused insulin injections. At one month post-discharge, serum triglycerides levels were $180 \mathrm{mg} / \mathrm{dL}$.

\section{Discussion}

Hypertriglyceridemia is diagnosed when the serum TG level exceeds $150 \mathrm{mg} / \mathrm{dL}$. The Adult Treatment Panel III of the National Cholesterol Education Program has suggested four TG strata: normal, <150 mg/dL; borderline high; 150-199 $\mathrm{mg} / \mathrm{dL}$; high, 200- $499 \mathrm{mg} / \mathrm{dL}$; and very high, $\geq 500 \mathrm{mg} / \mathrm{dL}^{2}$ The percentage of adults in the United States with TG levels above $150 \mathrm{mg} / \mathrm{dL}, 200 \mathrm{mg} / \mathrm{dL} 500 \mathrm{mg} / \mathrm{dL}$ and $1000 \mathrm{mg} / \mathrm{dL}$ is $33,18,1.7$, and 0.4 percent, respectively. ${ }^{3}$ Hypertriglyceridemia can be inherited as a primary familial trait in combination with dyslipidemia or can occur secondary to uncontrolled diabetes mellitus, obesity, alcohol consumption or estrogen therapy. More complex forms of secondary HTG develop with hypothyroidism, end-stage renal disease, nephrotic syndrome, human immunodeficiency virus (HIV) infection and many anti-HIV drugs. ${ }^{4}$ Patients with TG levels above $2000 \mathrm{mg} / \mathrm{dL}$ almost always have both a secondary and a genetic form of HTG. ${ }^{4}$

It is estimated that HTG accounts for $1 \%$ to $7 \%$ of all cases of acute pancreatitis. ${ }^{5}$ Exact mechanisms involved in acute pancreatitis arising from elevations in TG levels are not clearly understood. Currently, the most accepted mechanism, proposed by Havel, ${ }^{6}$ suggests that hydrolysis of TG by pancreatic lipase, in and around the pancreas, promotes the accumulation of free fatty acids in the pancreatic capillary beds. Free fatty acid accumulation results in capillary plugging, leading to ischemia and acidosis. It is postulated that the acidic environment results in trypsinogen activation and initiation of acute pancreatitis. ${ }^{6}$

Triglyceride levels greater than $1000 \mathrm{mg} / \mathrm{dL}$ to $1500 \mathrm{mg} / \mathrm{dL}$ require urgent treatment to reduce the risk of pancreatitis. ${ }^{7,8}$ The benefit of treating mild-to-moderate elevations in TG levels for prevention of acute pancreatitis is less clear. ${ }^{8}$ The duration of persistent elevation necessary to cause pancreatitis is unknown. ${ }^{5,9}$ Identification and elimination of secondary contributors is critical in alleviating ongoing TG-rich lipoprotein accumulation. Patients with TG levels above 2000 $\mathrm{mg} / \mathrm{dL}$ secondary to alcohol use benefit from alcohol abstinence. ${ }^{10,11}$ Avoidance of simple sugars, which have been associated with postprandial HTG, is also advised. ${ }^{12}$

Case reports have documented substantial decreases in serum TG following administration of heparin or insulin. Lipoprotein lipase is a crucial enzyme that is needed for removal of TG from plasma. It is produced by adipocytes and myocytes and is transported to the surface of endothelial cells where it becomes bound. Insulin promotes the synthesis of lipoprotein lipase, which hydrolyzes TG into fatty acids and glycerol and facilitates storage of the fatty acids in adipocytes. ${ }^{1}$ In a nondiabetic adolescent patient with severe HTG, a bolus dose of regular insulin $(0.1 \mathrm{U} / \mathrm{kg})$ given subcutaneously decreased 
serum TG from $1893 \mathrm{mg} / \mathrm{dL}$ to $1015 \mathrm{mg} / \mathrm{dL}$ after only 4 hours. ${ }^{13}$ Heparin promotes the release and translocation of tissue bound lipoprotein lipase in the capillary endothelium. Lipoprotein lipase hydrolyzes circulating TG into free fatty acids while it is bound to the luminal surface of the endothelial cell. Lipoprotein lipase is a high affinity heparin binding protein. It is released into the blood stream of humans and animals by intravenous injection of heparin. Heparin binding via the carboxyl terminal region is required to maintain lipoprotein lipase activity and probably prevents the conversion of enzyme into inactive monomeric units. Optimal lipoprotein lipase binding to heparin is required to localize lipoprotein lipase to proteoglycan-rich cell memebranes leading to efficient targeting of newly created fatty acids to tissues. ${ }^{14}$ Berger et $\mathrm{al}^{15}$ reported five cases where serum TG levels decreased to $<500 \mathrm{mg} / \mathrm{dL}$ in less than three days in all five cases. Jain et $\mathrm{al}^{16,17}$ also reported similar results in two other cases with insulin and heparin.

Use of plasmapheresis for removal of TG and chylomicrons from circulation has been reported. This intervention involved replacement of TG-rich plasma with salt-free human albumin or fresh-frozen plasma, thereby substantially reducing TG levels. Plasmapheresis was shown to decrease TG levels by as much as $70 \%$ within several hours. ${ }^{18}$ Low fat diet, supplements of omega-3 fatty acids (fish oil) and fibrates are recommended for long-term maintenance therapy. Drug therapy can effectively reduce TG levels by $20 \%$ to $60 \% .{ }^{19}$ In a study performed in 12 male patients with elevated TG, administration of nicotinic acid caused reduction of plasma TG by $52 \%$ in one month. ${ }^{20}$ Pooled meta-analysis of randomized placebocontrolled clinical trials demonstrated a reduction of TG by $30 \%$ in a mean duration of about five years. ${ }^{21}$ We demonstrated a $68 \%$ decrease in TG in 24 hours and believe that insulin infusion contributed significantly to this rapid decline. Moderate weight loss may be associated with reductions in TG levels. ${ }^{22}$

Our patient had several secondary risk factors for HTG including obesity, severe alcohol abuse, uncontrolled diabetes mellitus, and a sedentary life style. During his hospital stay, he was prescribed a low fat diet which excluded simple sugars, and he was counseled to abstain from alcohol consumption, this likely being the most influential of his secondary contributors. Administration of intravenous insulin was likely the major contributor in the rapid reduction of serum TG by $68 \%$ within a span of 24 hours. Insulin infusion presented in the context of this case report achieved outcomes comparable to those reported with plasmapheresis, at relatively lower cost and in a minimally-invasive manner. The patient continued on niacin (500 mg/day) and gemfibrozil $(600 \mathrm{mg}$ twice daily) for one month. He abstained from alcohol consumption and followed a low carbohydrate diet. After one month, his TG decreased to $180 \mathrm{mg} / \mathrm{dL}$, and he had no recurrence of abdominal pain.

\section{Conclusion}

Although HTG is a common form of dyslipidemia, very high elevation of serum TG can be associated with significant morbidity and mortality. Treatment with insulin infusion is an effective and minimally-invasive form of rapidly treating severe HTG in addition to other pharmacological agents.

\section{Acknowledgments}

The authors wish to thank the Marshfield Clinic Research Foundation's Office of Scientific Writing and Publication for editorial assistance in the preparation of this manuscript.

\section{References}

1. Sadur CN, Eckel RH. Insulin stimulation of adipose tissue lipoprotein lipase. Use of the euglycemic clamp technique. J Clin Invest 1982; 69:1119-1125.

2. Expert Panel on Detection, Evaluation, and Treatment of High Blood Cholesterol in Adults. Executive Summary of The Third Report of The National Cholesterol Education Program (NCEP) Expert Panel on Detection, Evaluation, And Treatment of High Blood Cholesterol In Adults (Adult Treatment Panel III). JAMA 2001;285:2486-2497.

3. Ford ES, Li C, Zhao G, Pearson WS, Mokdad AH. Hypertriglyceridemia and its pharmacologic treatment among US adults. Arch Intern Med 2009;169:572-578.

4. Yuan G, Al-Shali KZ, Hegele RA. Hypertriglyceridemia: its etiology, effects and treatment. CMAJ 2007;176:1113-1120.

5. Yadav D, Pitchumoni CS. Issues in hyperlipidemic pancreatitis. J Clin Gastroenterol 2003;36:54-62.

6. Havel RJ. Pathogenesis, differentiation and management of hypertriglyceridemia. Adv Intern Med 1969;15:117-154.

7. Brunzell JD, Deeb SS. Familial lipoprotein lipase deficiency, apo CII deficiency and hepatic lipase deficiency. In: Scriver CR, Beaudet AL, Sly WS, Valle D, eds. The Metabolic and Molecular Bases of Inherited Disease, Volume 1. 8th ed. New York, NY: McGraw-Hill, 2001. 2789-2816.

8. Brunzell JD, Schrott HG. The interaction of familial and secondary causes of hypertriglyceridemia: role in pancreatitis. Trans Assoc Am Physicians 1973;86:245-254.

9. Gan SI, Edwards AL, Symonds CJ, Beck PL. Hypertriglyceridemia-induced pancreatitis: A case-based review. World J Gastroenterol 2006;12:7197-7202.

10. Kyriakidis AV, Raitsiou B, Sakagianni A, Harisopoulou V, Pyrgioti M, Panagopoulou A, Vasilakis N, Lambropoulos S. Management of acute severe hyperlipidemic pancreatitis. Digestion. 2006;73:259-264.

11. Alagözlü H, Cindoruk M, Karakan T, Unal S. Heparin and insulin in the treatment of hypertriglyceridemia-induced severe acute pancreatitis. Dig Dis Sci 2006;51:931-933.

12. Havel PJ. Dietary fructose: implications for dysregulation of energy homeostasis and lipid/carbohydrate metabolism. Nutr Rev 2005;63:133-157.

13. Jabbar MA, Zuhri-Yafi MI, Larrea J. Insulin therapy for a nondiabetic patient with severe hypertriglyceridemia. J Am Coll Nutr 1998; 17:458-461.

14. Lutz EP, Merkel M, Kako Y, Melford K, Radner H, Breslow JL, Bensadoun A, Goldberg IJ. Heparin-binding defective lipoprotein lipase is unstable and causes abnormalities in lipid delivery to tissues J Clin Invest 2001;107:1183-1192.

15. Berger Z, Quera R, Poniachik J, Oksenberg D, Guerrero J. [Heparin and insulin treatment of acute pancreatitis caused by hypertriglyceridemia. Experience of 5 cases.] [article in Spanish.] Rev Med Chil 2001;129:1373-1378.

16. Jain D, Zimmerschied J. Heparin and insulin for hypertriglyceridemia-induced pancreatitis: case report. ScientificWorldJournal. 2009;9:1230-1232. 
17. Jain P, Rai RR, Udawat H, Nijhawan S, Mathur A. Insulin and heparin in treatment of hypertriglyceridemia-induced pancreatitis. World J Gastroenterol 2007;13:2642-2643.

18. Lams E. Pancreatitis and hypertriglyceridaemia. Eur J Anaesthesiol 2006;23:1067-1068.

19. Oh RC, Lanier JB. Management of hypertriglyceridemia. Am Fam Physician 2007;75:1365-1371.

20. Grundy SM, Mok HY, Zech L, Berman M. Influence of nicotinic acid on metabolism of cholesterol and triglycerides in man. J.Lipid Res 1981;22:24-36.

21. Saha SA, Kizhakepunnur LG, Bahekar A, Arora RR. The role of fibrates in the prevention of cardiovascular disease--a pooled meta-analysis of long-term randomized placebocontrolled clinical trials. Am heart J 2007;154:943-953.

22. Knowler WC, Barrett-Connor E, Fowler SE, Hamman RF, Lachin JM, Walker EA, Nathan DM; Diabetes Prevention Program Research Group. Reduction in the incidence of type 2 diabetes with lifestyle intervention or metformin. N Engl J Med 2002;346:393-403.

\section{Author Affiliations}

Sujani Poonuru, MD*; Sumedha R. Pathak, MD*;

Hemender S. Vats, MD*; Ram D. Pathak, MD ${ }^{\dagger}$

*Department of Internal Medicine, Marshfield Clinic, Marshfield, WI USA

tDepartment of Endocrinology, Marshfield Clinic, Marshfield Wisconsin USA 